Reviews \& Debates

\title{
WHAT IS DEMOCRATIC SOCIALISM? WHAT IS SOCIALIST DEMOCRACY?
}

\author{
BY PETER HUDIS \\ Review of Alexandros Chrysis, 'True Democracy' as a Prelude to Communism: The Marx \\ of Democracy (Basingstoke: Palgrave Macmillan, 2018)
}

\begin{abstract}
This review of the new book by Alexandros Chrysis explores the meaning of democratic socialism and socialist democracy through a discussion of Marx's early writings on politics (1837-43) in terms of their political and philosophical significance for today.
\end{abstract}

I.

The past several years has witnessed an explosion of interest in socialist theory and practice-and especially of democratic socialism. This is hardly accidental. As a new generation of activists seeks to develop a viable alternative to capitalism, the spectre of failed efforts to create a socialist society-both in the past and present-looms large. This spectre cannot be simply willed away, since it is objectively rooted in 100 years of radical theory and practice that either emphasized democratic liberties at the expense of a revolutionary uprooting of capitalism or reduced "socialism" to authoritarian state control that suppresses democracy. Envisioning and forging a truly democratic socialism and a socialist democracy has proven to be an extremely fraught and difficult project. In light of this, it becomes important to explore theoretical sources that provide direction for working out a truly revolutionary democratic socialism for our times.

Alexandros Chrysis's 'True Democracy' as a Prelude to Communism: The Marx of Democracy represents a vial contribution to this effort. It does not directly explore how postMarx Marxists viewed the relation between democracy and socialism; nor does it pretend to present Marx's views on the subject as a whole. The book (the first in a series by Chrysis on Marx's political theory) is about the young Marx, before he broke from bourgeois society and embraced communism. While the young Marx (1837-43) has been exhaustively explored by many scholars, Chrysis goes further than others in showing that the young Marx's advocacy of democracy informed the very understanding of communism found in his later work. It represents, in the mind of this writer, one of the most important works on Marx and Marxism to have appeared in the last decade. 
Chrysis suggests throughout his study that his account of the young Marx's passage from a radical democrat to a socialist or communist ${ }^{1}$ is not merely of historical or academic interest. He writes, "I therefore wish to state the following at the outset: the enigma of democracy, as a form of transition to socialism and as a form of organization of a socialist society and its political avant-garde per se, has not been solved." ${ }^{2}$ This is a striking statement, given the enormous amount of discussion and debate among socialists over questions of democracy over the past two centuries. Prior to the rise of Stalinism (in the 1920s), socialists were in virtual unanimous agreement that a democratic republic was the form best suited for waging the struggle for a new society. The socialists of the First and Second International saw no contradiction between promoting democratic reforms within existing society (such as universal suffrage, freedom of speech and the press, universal public education, etc.) while calling for the abolition of capitalism; indeed, they assumed that expanding democratic liberties would enable workers to wage the class struggle to a successful conclusion. Engels, Kautsky Plekhanov, Luxemburg, and Lenin all held this position. ${ }^{3}$ Yet while few doubted that democracy is vital in paving the way for socialism, there was less unanimity about democracy as a form of organization of socialism. For statist and authoritarian Marxists, democracy became viewed as a "cumbersome mechanism"4 that could be cast aside in the transition to socialism-if not entirely suppressed (as with Stalin, Mao, and "Marxist-Leninist" regimes in the developing world). Far from posing an alternative to capitalism, these efforts resulted in state-capitalist regimes that were neither socialist nor democratic. Meanwhile, Social Democrats who supported political democracy abandoned the struggle for socialism in the years following the "great betrayal" of 1914 and limited themselves to advocating Keynesian measures of income redistribution within a capitalist framework. The ideological claim that became so powerful over the last several decades-that "there is no alternative to capitalism"-did not only arise because of the actions of political reactionaries; it is also a consequence of the failure of the radical movements to actualize the organic connection between socialism and democracy. ${ }^{5}$

It is this crisis, Chrysis suggests, that provides a vantage point for re-examining Marx's journey from a radical democratic to a communist. The work of the young Marx, he argues, "helps us read the traumatic relationship between socialism and democracy and design a possible future congruence between a Marxist theory of democracy and communism as a viable project for humanity." ${ }^{\prime}$ No small matter, since the direction in which we are headed suggests that humanity will not have much of a future if the transcendence of capitalism does not become embraced as a viable project.

II.

It is widely acknowledged that from his earliest writings Marx was a fervent advocate of political democracy. He strongly opposed press censorship, restrictions on freedom of thought and expression, and authoritarian government. No one denies that the defense of democracy is a 
major theme of his early work. Far more more controversial, however, is Chrysis's claim that Marx developed a distinctive position on political issues in the early 1840 s which he transcended but did not not abandon or leave behind when he became a communist. His meticulous tracing out of the process by which Marx evolved from a radical republican (in 1840-42) to an advocate of what he called "true democracy" (in 1843) undermines the claim (made by Cornelius Castoriadis, Dick Howard, and Allan Megill) that he lacked a coherent political theory. It is also undermines the claim (made by Maximilien Rubel and Lucio Colletti) that the political thought of the young Marx was copied from earlier thinkers such as Spinoza or Rousseau. Even before he broke from bourgeois society, Chrysis argues, Marx carved out a distinctive position on political issues that informed much of his later work as a revolutionary socialist.

Marx's approach to politics flowed form a philosophical conception of the relation between the ideal and real. His earliest writings adopt the Hegelian approach of "seeking the idea in reality itself." Instead of making a priori claims about what ought to be, he seeks to discover political forms that express humanity's social being. His political theory is rooted in social ontology-in a specific view of human capacities. He does not assume that humanity is naturally anti-social and egotistical; instead, we are social beings capable of conscious, purposeful activity. ${ }^{8}$ In contrast to Kant, Locke and other classical liberals, Marx treats politics as the expression or actualization of our social nature, not as a corrective to its absence. This is of decisive importance, since it means that the young Marx opposes social contract theory-the basis of most liberal (and much radical) thought. Politics, according to social contract theory, has the express purpose of suppressing our natural inclination to pursue individual interests at the expense of collective ones. The particular (the individual) and the universal (the social totality) are viewed as mutually exclusive. Marx rejects the idea that politics is an external corrective to our "fallen" state as early as his Doctoral Dissertation (1839-41) $)^{9}$ and writings in defense of freedom of speech and the press. He wrote in 1842 , "Freedom is so much the essence of man that even its opponents implement it while combatting its reality... No man combats freedom; at most he combats the freedom of others. Hence every kind of freedom has always existed, only at one time as a special privilege, at another as a universal right." ${ }^{10}$ Marx proceeds to measure existing realities (social inequality, the state, civil society, and eventually private property) against the possibilities intrinsic to our social being. ${ }^{11} \mathrm{He}$ writes, "The state cannot go against the nature of things" 12 Insofar as the state acts to protect the interest of a few at the expense of the many, it violates our social nature. The young Marx is therefore highly critical of the existing state-so much so that he turns against Hegel's political writings that apologize for it. ${ }^{13}$ But he was never a liberal democrat; prior to 1843 , he was a radical republican.

The distinction between liberal democrats and radical republicans largely rests upon their views of the state. For classical liberals, the state is a necessary evil that mediates conflicts between egoistic individuals while enabling the pursuit of private interests. For radical republicans (which included many of Marx's friends among the Young Hegelians), the state is a 
positive good that provides a moral and political framework for maintaining and enhancing intersubjective interests. Radical republicans attacked the rampant individualism of liberalism as well as the oppressive statism of existing governments. Marx enters this debate in 1842 by stressing the difference between a "rational state" and the existing state. The latter is irrational since it does not correspond to the idea of freedom. In Hegelian parlance, the existing state is not adequate to its concept, since a state is by definition a community of beings with rational capacities. A state based on maintaining the power and privilege of the few is irrational and deserves to perish. This does not mean that the young Marx opposes the existence of states per se; he opposes states that do not embody rational principles. Republicanism is not anarchism. But neither is it Marxism, since he has yet to conceive of the state as an expression of class domination. Nevertheless, he has already clearly differentiated himself from liberalism, since he holds that social contract theory rests upon irrational premises. While Hobbes and Locke contend that we become aware of the need to submit to a higher authority in order to escape the incessant warfare that characterizes the state of nature, decisive in this is not reason but fear-an irrational emotion. The entire liberal justification for the modern state therefore rests on irrational premises. And so it remains.

There are clearly idealist elements in the young Marx that he later surpasses. But it is a serious mistake to dismiss or downplay his early political writings on the grounds of "the painful inadequacy of his idealistic world conception," voiced in "a wild, half-understandable tongue," as Rosa Luxemburg once put it. ${ }^{14}$ Marx was never an idealist in the sense of positing a set of a priori conceptions divorced from material realities. At this point, he has not yet reached the point of discovering the secret of those realties in the critique of political economy. But the overall approach found in his earliest work is the same as in his mature work. He sums it up (in 1842): "The form is of no value if it is not the form of the content." 15 Thus, the form of political life is viable only insofar as it expresses the possibilities immanent in us as conscious, purposeful, social beings.

Chrysis articulates this as follows: "Following the Marx of democracy, an individual is free as a member of a polity not just when they move unfettered within the frame of the law that instrumentally or mechanically protects their goods and rights, but as far as the law manifests and forms the essence of a human being as an organic and rational member of the community... In other words, in the context of the republican polity like the one proposed and defended by Marx in Rheinische Zeitung, freedom presupposes and represents the historical activation and cultivation of consciousness as the human being's ontological feature of living politically according to reason." ${ }^{16}$

The ontological grounding of Marx's defense of democracy is tremendously important, since it means he did not have an instrumental view of politics. He does not view politics as a tactical or strategic tool to attain goals irrespective of our human nature. Of course, Marx is not unique in having a concept of politics that flows from a particular understanding of the human condition. That is true of everyone. Liberals assume that our natural state is egotistical self- 
interest. They therefore view politics as an instrument to compel people to act unnaturally. This serves as the basis of their view of law, the state, the criminal justice system, etc. Ironically, many leftwing critics of liberalism proceed from the same premise. They too treat politics as an instrument or tool for securing power (always "in the interests of the masses," of course). And they do so because they have as impoverished an understanding of human nature as the liberals (the work of Slavoj Zizek is a case in point). Chrysis takes issue with Fredric Jameson, who thinks Marx's economic writings outweigh his political ones since the latter are "merely tactical." Jameson apparently does not see that Marx proceeds from a conception of human capacities that argues against treating politics (including political organization) as a merely tactical or strategic consideration. Chrysis correctly considers such a position to be "dangerous politically." ${ }^{17} \mathrm{~A}$ politics that is completely reduced to tactics and strategy lacks any ontological grounding. Actions are taken to advance particular causes, without regard to whether they augment or suppress human capacities. Aside from reproducing the old notion of "the end justifies the means," this leaves us without a yardstick with which to measure the validity of any political project or action. And if that is missing, it becomes easy to justify even the most objectionable actions in the name of "the socialist cause." 18

Here is where the Marx of democracy is quite distant from later Marxists who talk endlessly of material conditions, without pinpointing the most important material condition of all-the distinct set of capabilities that constitute the human essence. They posit a material determinism (especially in emphasizing "the economic factor") while having a completely indeterminate and voluntarist view of politics. But if material conditions are the basis of social existence, it follows that the political forms adopted at any point in time have to correspond to the possibilities inherent in them. It goes without saying, of course, that those who reject an ontological foundation for politics on the grounds that all notions of a human essence are untenable expressions of an ahistorical "essentialism" will hardly be convinced of this. But it cannot be denied that anti-foundationalist standpoints, so common today among postmodernists, postcolonial theorists, and others in the academy, leaves us bereft of any philosophical basis from which to measure the efficacy of interventions in politics (which is one reason many who adopt this stance refrain from engaging in actual politics). Marx himself, however, is no metaphysical foundationalist, since he proceeds not from a priori assumptions about the good life but rather from an understanding of the real material conditions of social existence. ${ }^{19}$

III.

This dimension of Marx's work becomes further developed and fleshed out in his lengthy unpublished "Contribution to the Critique of Hegel's Philosophy of Right" of 1843. It marks a critical turning point in Marx's thinking. He now moves beyond the framework of radical republicanism and the demand for a "rational state," and posits, through a critique of Hegel's 
political philosophy, a conception of what he calls "true democracy"-which becomes the transition point for his conversion to communism only a few months later.

Chrysis sees Marx's 1843 critique of Hegel as "an elaborated and developed version and supersession of Marx's previous studies and writings." ${ }^{20}$ Marx concludes by 1843 that the theory of the state has reached a critical impasse and that a new beginning is needed. What largely inspires this is his recognition that existing political theory (including Hegel's) has reached an impasse when it comes to the question of poverty.

It is hardly possible to have a truly democratic society, Marx recognizes, so long as a section of humanity is condemned to poverty. A body politic based on republican principles can be actualized only when all individuals participate in political life, not only those who possess the economic means to do so. And yet the political theorists of the day made little or no progress in explaining why poverty persists and how it can be overcome. Hegel writes that the problem cannot be resolved by relying on the actions of the private individuals of civil society, who have neither the means nor the interests to end poverty. He therefore invokes the state as the active principle that stands above civil society. But Hegel recoils from proposing any radical measures that could actually eliminate property. Nor is this a problem of Hegel alone. While liberal and republican theory place great emphasis on the ability of legislative bodies to regulate social inequities, Marx begins to see that such economic problems as endemic poverty cannot be eliminated by political reforms from above. Hegel is wrong, he realizes, to posit the state as above civil society. The active agent or subject of modern society is not the state; it is civil society itself. So long as the contradictions of civil society remain intact-foremost among them the contradiction between those who have the "right" to property versus those who lack it - the problem of poverty and inequality will persist. Chrysis summarizes Marx's view thusly: "Contrary to Hegel's arguments, the legislative power, which inculcates in se the real antagonisms of civil society, proves to be structurally and functionally ineffective in regulating and overcoming those antagonisms."21

If civil society is the subject and the state is the predicate, it follows (Marx notes) that it is only "with the fall of the 'state of civil society' the fall of the 'civil society of the state [occurs]'."22 Marx is taking a very radical position here, since it "raises the demand for the simultaneous dissolution of civil society and the political state." ${ }^{33}$ The state is "a false universal," a "hieroglyph of reason." ${ }^{24}$ A rational state is impossible given the nature of civil society. The economic structures of civil society must be radically transformed in order to create what Marx calls "true democracy" - a democracy that overcomes the false democracy of today, in which the few that own the means of production lord over the many who do not. Chrysis writes, "Marx's critique of the Hegelian philosophy of the state would soon reach not only the theoretical deconstruction of the Hegelian philosophy of the state, but also the transcendence of Marx's own concept of a rational or republican state, showing that freedom in terms of the autonomy or selfdetermination of the people will remain an unfulfilled goal until the political state, even in its republican form, is dissolved in the context of 'true democracy'."25 
Marx's embrace of "true democracy" pushes him to the far left of the radical democrats of the time, since he has pointed to the need for the political critique of the state to be coupled with an economic critique of civil society. But he has not yet fully entered into that economic critique. Nor has he identified the subjective element that can uproot civil society from within and thereby resolve the contradiction between those who possess property and those who lack it-the proletariat. That will come with his break from bourgeois society several months later, after completing his critique of Hegel's political theory in his "Introduction to the Critique of Hegel's Philosophy of Right" (at the very end of 1843) and moving to Paris, where he makes contact with revolutionary communist workers (at the beginning of 1844). However, the direction in which he is traveling is already evident. The 1843 critique of Hegel attacks the idea of "a peaceful and gradual readjustment of the existing constitution through a legislative body" because, "for a new constitution a real revolution has always been required." ${ }^{26}$ But what is meant by a "real revolution"? And what does it have to do with the challenges facing us today?

Statist socialists think that capitalism can be abolished in making use of the state. Anarchists think that capitalism can be abolished by smashing the state. They draw opposite conclusions while proceeding from the same premise: namely, that the state is the independent, not the dependent variable of social life, and as such it is the pivot upon which social transformation turns.

From his critique of Hegel's Philosophy of Right, Marx discovers that this seeming independence and sovereignty of the state is an illusion. To be sure, the state appears to be powerful-even infinitely powerful. However, it is not as powerful as it appears, since it is actually the dependent, and not the independent, variable. So long as civil society is based on egotistical self-interest, in which individuals compete with each other irrespective of the common good, the state is needed to mediate and control the interminable tensions and conflicts that are endemic to that society. The state is an abstraction, but a real abstraction called forth by specific social relations. It is the result or predicate, not the subject or active agent; yet it appears, and must appear, as the subject or active agent, because of the contradictions of civil society, the foremost of which is the separation of particular from universal interests.

Illusions that necessarily flow from existing social relations are very difficult to dispel, since they express real contradictions. It should therefore come as no surprise that not only supporters of capitalism, but also many of its most virulent critics, fall victim to the illusion that the state is the pivot upon which social transformation turns. Statist socialists such as Social Democrats, Stalinists, "Marxist-Leninists," and Trotskyists see the capture of state power as the essential precondition for creating socialism, ${ }^{27}$ while anarchists and autonomists view the rejection of state power as the essential precondition. The Marx of 1843-and I would argue, from then to the end of his life-has a distinctly different view. He is critical of the state, but understands that is is not omnipotent since it is dependent on the contradictions of civil society. He therefore conceives of the transformation of civil society as the pivot upon which social transformation turns. As a revolutionary upsurge eliminates the economic and political 
domination of the ruling classes, the antagonistic character of social relations begins to be overcome, rendering superfluous the need for a state that stands above and controls social life. Society asserts itself at the expense of the state in the revolutionary transition to true democracy and socialism. Marx spells this out decades later, in his writings on the Paris Commune, in the following terms:

"This was a Revolution not against this or that, legitimate, constitutional, republican, or Imperialist form of State Power. It was a Revolution against the State itself, this supernaturalist abortion of society, a resumption by the people for the people, of its own social life. It was not a revolution to transfer it from one fraction of the ruling classes to the other, but a Revolution to break down this horrid machinery of class domination itself." 28 He adds: "The Commune-the reabsorption of the State power by society, as its own living forces instead of as forces controlling and subduing it, by the popular masses themselves, forming their own force instead of by the organized force of their suppression... The form was simple like all great things." ${ }^{29}$

Marx's striking formulation to the effect that the political form needed to transition from capitalism to socialism is "the reabsorption of the State power by society" through a new, "nonstate form" (his term, which is how he understood "the dictatorship of the proletariat") is often considered a novel conception on his part, arrived at after years of intense reflection on the problem of social transformation. That is surely correct, but it is also the case that he posited the conceptual basis of this formulation all the way back in his 1843 critique of Hegel's Philosophy of Right-even before he became a communist!

The Marx of 1843 and of 1871 may have had different politics, but the underlying conception that the transition to "true democracy" hinges upon asserting the power of society over that of the state is integral to both. Chrysis articulates this with stunning clarity. Already in 1843, he notes, "Marx would raise the question of democracy as people's self-determination, while arguing for the absorption of the political state within society itself." ${ }^{30}$ A singular political conception characterizes both the young and the mature Marx: that the solution to the predicament of the modern world lies in society asserting its power over that of the state. A critical difference between Marx's work before and after 1843 is that Marx sees in the later that this can be achieved only if the political economy of civil society is uprooted from below, beginning with a revolutionary transformation of human relations at the point of production. The "mature" critic of political economy and philosopher of revolution of 1871 thereby bring into sharper focus and actualizes the conception that helped take him on the path to breaking from capitalism at the very end of 1843.

Chrysis writes: "The pre-communist Marxian theory of democracy, as well as its innate relationship with Enlightenment theory, does not disappear in Marx's mature work, but is introduced dialectically in his theory of class struggle and the complex dynamics of the conflict between the bourgeoisie and the proletariat." 31

Why should this matter for us now? It matters because the emancipatory conception that Marx developed, starting in 1843 and culminating in 1871, needs to be recovered for today in 
light of the historical failure of post-Marx Marxism to actualize a dialectical relationship between democracy and socialism. In lieu of this, it becomes all-too-easy to repeat the errors of the past. Antonio Gramsci once noted, "History teaches, but has no pupils." Marx's body of thought is integral to history, and now is as good a time as any to learn from it-whether we are new to Marxism or not.

IV.

This journey through the political writings of the young Marx suggests that the creation of socialism depends upon the actualization of true democracy. The latter is not a mere means to be discarded upon reaching the socialist future. Socialism is not an additive to an already-existing institution called democracy. Nor is democracy a mere expression of class society that will vanish with its passing. Socialism is the actualization of democracy-its first true appearance.

As Chrysis writes, this relationship is difficult to conceptualize, let alone actualize. One reason is that "to the extent that the distinction between civil society and the political state is valid and continues to operate, representation can only serve particularist interests." 32 This helps explain why virtually every time leftist political parties, individuals, or movements enter the halls of state power they become less radical and assert some interests at the expense of others-often to the detriment of the most marginalized and exploited sections of society. What disappears is the advocacy of universal interests that benefit the common good. This cannot be explained simply by "corruption," "opportunism," or personal failings. All these may play a part, but something deeper is at issue, which Marx recognized in the early 1840s: that since civil society, and not the state, is the active agent of social life, transformations at the level of the state will only reach as far as the transformation of civil society. And civil society includes not only property and class relations, but also the family, relations between the races and ethnicities, and all the other components of Sittlichkeit (social customs and norms) that come under the order of ethical life. These must serve as the fulcrum of social critique and transformation, without which all efforts to resolve existing social contradictions at the level of representation will prove fruitless.

Does this mean that we should refrain from politics and not contest the power of the existing state? Of course not! Such a withdrawal from politics is anathema to the Marxian project. Politics is the expression of our social being. This is why as much as Marx opposed bourgeois politics, he was not against participating in parliamentary elections so long as doing so can advance the class struggle-especially when such involvement is connected to a vibrant mass movement. If positing a priori principles divorced from material conditions is antithetical to the Marxian project, so is abstaining from engaging in political formations that are part of our daily social existence. These are by no means limited to the forms of the state, but they surely include them. Yet to the extent that we participate in them, it must be from a critical standpoint that transcends the horizon of parliamentarism in which the illusion that social change at the level of legislation is the fulcrum for transforming society is thoroughly refuted. The deepest and most 
long-lasting social transformations are those that come from below, as the entire history of the feminist, labor, civil rights and LBGTQ struggles show.

Chrysis's work points to Marx's political differences not only with statist socialists, but also with anarchists. It is widely assumed that Marx shared the same goal as anarchists since he views the state as an "excrescence" of class society that will perish with its passing. That is true insofar as the abolition of the state in a future socialist or communist society is concerned. But it is not true in terms of the future of politics. True democracy as genuine socialism has as its goal not the end of politics but the end of a certain kind of politics, since democracy is a political formation. It is not an instrumental form that has no relation to our human potential. We cannot actualize our social being through hierarchical institutional forms based on class, race and other forms of privilege. Nor can it be actualized by practices that (to use Marx's 1844 formulation) treat women as "the spoil and handmaid of communal lust."33 The deliberation, negotiation and debate needed to create non-alienated human relations is a political project that will concern us long after we have dispensed with capitalism.

Chrysis concludes, "I have argued throughout that the Marxian 'true democracy' is not a state in the sense of an apparatus that is separate from civil society; 'true democracy' as a political community, a political Gemeinschaft, is clearly differentiated from and opposed to the theory and practice of a political state. Consequently, the argument that, according to Marx, political deliberations and decision making through political institutions and procedures have no meaning in a future stateless society constitutes a major misunderstanding of the Marxian theory of democracy... The Marxian polity is not a quasi-anarchic or libertarian open assembly, which appears and functions occasionally in terms of spontaneity...politics permanently remains a critical moment of the social totality, within which the distinction between civil society and the state ceases to exist." 34

\footnotetext{
${ }^{1}$ The terms "socialism" and "communism" - as well as "new society," "free association of producers," "realm of free individuality," etc.-are interchangeable in Marx's work and do not denote distinct political projects or historical stages. I will use them interchangeably in this essay as well.

${ }^{2}$ Alexandros Chrysis, 'True Democracy' as a Prelude to Communism: The Marx of Democracy (Basingstoke: Palgrave Macmillan, 2018), p. 3.

${ }^{3}$ For more on this, see my Introduction to J.P. Nettl, Rosa Luxemburg (New York and London: Verso Books, 2019), pp. ix-xxiii.

${ }^{4}$ Leon Trotsky and V.I. Lenin infamously used this term to justify their suppression of democracy following the Bolshevik Revolution of 1917. For a critique of their position, see Rosa Luxemburg, The Russian Revolution, in The Rosa Luxemburg Reader, edited by Peter Hudis and Kevin B. Anderson (New York: Monthly Review Books, 2004), pp. 299-310.

${ }^{5}$ A crucial expression of this problem is its impact on organization-which Chrysis refers to as socialism's "political avant-garde per se." The tendency of radical parties, committees, and sects to flounder or fall apart because of the lack of democratic accountability is ubiquitous. For an analysis of this problem, see Peter Hudis, "Political Organization," in The Marx Revival, edited by Marcelo Musto (Cambridge: Cambridge University Press, forthcoming).
} 
6 'True Democracy' as a Prelude to Communism, p. 104.

7 "Letter from Marx to His Father" [1837], in Marx-Engels Collected Works, vol. 1 (New York: International Publishers, 1975), p. 178. Hereafter "MECW."

${ }^{8}$ The influence of Aristotle, who famously held that "humanity is a political animal," is not hard to see. Marx's debt to Aristotle's Politics and Ethics, both before and after he became a communist, is incontestable.

${ }^{9}$ In his Dissertation Marx quotes Epicurus: "Natural right is a mutual agreement, contracted for the purpose of utility" (MECW, vol. 1, p. 409). Later, in The German Ideology, he will write: "The idea that the state rests on mutual agreement of people, on a contract social, is found for the first time in Epicurus" (MECW vol. 5, p. 141).

10 "Debates on Freedom of the Press," in MECW, vol. 1, p. 155.

${ }^{11}$ Contrary to the claims of many of his critics, Marx's conception of humanity's "species-being" in no way, shape or form subsumes or leaves out the individual. As Marx writes in the Economic and Philosophic Manuscripts of 1844, "Above all, we must avoid postulating 'society' again as an abstraction vis-à-vis the individual. The individual is the social being" (MECW, vol. 3, p. 299). And his 1843 critique of Hegel's Philosophy of Right, as well as many other writings, singles out the importance of individual agency. Joseph V. Femia completely misconstrues Marx's position in claiming "Marxism's 'holistic' ontology, which collapses the distance between the individual self and the 'ensemble of social relations' (Marx's words), prevents Marxists from seeing the human subject as a sovereign agent of choice, a creature who acquires his or her aims and purposes by acts of will rather than acts of discovery." See his Marxism and Democracy (Oxford Introductions). (Oxford: Oxford University Press, 1993), p. 3.

12 "Debates on the Law on the Thefts of Wood," in MECW, vol. 1, p. 257.

${ }^{13}$ Although this critique is fully developed in Marx's 1843 "Critique of Hegel's Philosophy of Right," he already has it in mind as early as his Doctoral Dissertation of 1839-41. As Raya Dunayevskaya argues in her pioneering discussion of Marx's earliest writings, "It was both Hegel and the living Left Hegelians (of which he was one) that Marx was challenging [in his Dissertation]. His point was that it was insufficient simply to show that the master [Hegel] has accommodated himself to reality. One must analyze the accommodation not merely to expose it but in order to discover the principle which compelled that accommodation." Rosa Luxemburg, Women's Liberation, and Marx's Philosophy of Revolution (Champaign-Urbana: University of Illinois Press, 2001), p. 122.

${ }^{14}$ See Luxemburg's “Aus dem Nachlaß unsurer Meister," in Gesammelte Werke, vol. 1.2 (Berlin: Dietz Verlag, 1990), pp. 138.

15 “The Divorce Bill. Editorial," in MECW 1, p. 275.

16 'True Democracy' as a Prelude to Communism, p. 77.

${ }^{17}$ Ibid., p. 19.

${ }^{18}$ One reflection of this is the crisis leftist organizations (such as the British Socialist Workers Party and the nowdefunct U.S. International Socialist Organization) faced in concealing serious sexual abuse and rape of women members. If "revolutionary politics" is defined in instrumental terms without regard to its philosophical grounding, the door to such disasters is left wide open. The ISO leadership apparently decided that maintaining the unity of the organization was more important than informing the membership of a rape by one of its leaders, since the organization's existence was seen as a crucial instrument for building a socialist movement. Political instrumentalists never ask what are the human capacities and capabilities that socialism or a socialist organization is meant to advance. If the only consideration is the goal (socialism) and the means to get there (the organization) without measuring both by an understanding of what it means to be human then all we have to go on are pragmatic considerations. There is no yardstick by which to measure anything. All judgments become relative. In this regard, we should never forget that when Marx posited humanity's "species-being" as the essence of our social existence, he did so while insisting that the treatment of women is "the measure" (as he put it) or of the response to such a society by its radical critics.

${ }^{19}$ In this sense, Marx's statement in the "Theses on Feuerbach" captures the exact conception I am defending here: "But the essence of humanity is no abstraction inherent in each single individual. In its reality it is the ensemble of 
social relations" (MECW vol. 5, p. 4). If this constitutes "essentialism," I have no problem being called an "essentialist."

20 'True Democracy' as a Prelude to Communism, p. 107.

${ }^{21}$ Ibid., p. 154.

${ }^{22}$ Contribution to the Critique of Hegel's Philosophy of Law [Right], in MECW, vol. 1, p. 45.

${ }_{23}^{2}$ 'True Democracy' as a Prelude to Communism, p. 179.

${ }^{24}$ Contribution to the Critique of Hegel's Philosophy of Law, p. 46.

25 'True Democracy' as a Prelude to Communism, p. 122.

${ }^{26}$ Contribution to the Critique of Hegel's Philosophy of Law, p. 56.

${ }^{27}$ In case the inclusion of Trotskyism raises any eyebrows, consider the following statement of Leon Trotsky, made in 1920: "The road to socialism lies through a period of the highest possible intensification of the principle of the state... Just as a lamp, before going out, shoots up in a brilliant flame, so the state, before disappearing, assumes the form of the dictatorship of the proletariat, i.e., the most ruthless form of state, which embraces the life of the citizens authoritatively in every direction" (Terrorism and Communism: A Reply to Karl Kautsky (London: New Park Publications, 1975), p. 177. This could not be further removed from Marx and Engels's conception of "the dictatorship of the proletariat."

28 "Drafts of The Civil War in France," in MECW, vol. 24, p. 486.

${ }^{29}$ Ibid., p. 487.

30 'True Democracy' as a Prelude to Communism, p. 109.

${ }^{31}$ Ibid., p. 7.

${ }^{32}$ Ibid., p. 167.

${ }^{33}$ Economic and Philosophic Manuscripts of 1844, in MECW vol. 3, p. 295.

34 'True Democracy' as a Prelude to Communism, pp. 210, 211-12. 